\title{
Proceeding
}

Supplementary Issue: Rio 2016 Olympic Games Third Anniversary Special Edition. Olympic Studies Forum, 2-3 September 2019. Federal University of Sergipe, Aracaju, Brazil

\section{Values and attitudes in social sport: A test of the explanatory model of values and attitudes of sport}

\author{
RICARDO PEDROZO SALDANHA ${ }^{1}$, MARCUS LEVI LOPES BARBOSA ${ }^{2}$, MARCOS ALENCAR ABAIDE \\ BALBINOTTI $^{3}$, CARLOS ADELAR ABAIDE BALBINOTTI ${ }^{4}$ \\ ${ }^{1}$ La Salle University (Unilasalle), Brazil \\ ${ }^{2}$ Feevale University, Brazil \\ ${ }^{3}$ University of Quebec at Tróis-Revières, Canada \\ ${ }^{4}$ Federal University of Rio Grande do Sul, Brazil
}

\begin{abstract}
Objectives: validate the explanatory model of values and attitudes in sport - EMVAS - and explore associations between important values variables and sports attitudes; Design: Data analysis of the Questionnaire of Variable Control Identification (QVCI), Inventory of Values from Juvenile Sport 2 (IVJS-2), Questionnaire of Attitudes in Sports (QAS-16) and Perceived Motivational Climate in Sport Questionnaire(PMCSQ-2); Methods: 1,125 participants (male $=687$; female $=438$ ) between the ages of 12 and 19, linked to grassroots social programs in southern Brazil with a variety of sports modalities; Results: Linear regressions using the 'stepwise' and 'enterwise' method (route analysis) indicate that there is a causal relationship between the links evaluated from 'Values' (predictor variables), 'Motivational Climate' (intermediate variables) and 'Attitudes' (predicted variables); Conclusions: there was evidence of the validity of EMVAS in the context of social sport. Keywords: Sports Values; Motivational Climate; Sports Attitudes.
\end{abstract}

\section{Cite this article as:}

Saldanha, R.P., Barbosa, M.L.L., Balbinotti, M.A.A., \& Balbinotti, C.A.A. (2020). Values and attitudes in social sport: A test of the explanatory model of values and attitudes of sport. Journal of Human Sport and Exercise, 15(1 proc), S57-S70. doi:https://doi.org/10.14198/jhse.2020.15.Proc1.07

\section{Corresponding author. University of La Salle (Unilasalle), Brazil.}

E-mail: ricardo.saldanha@unilasalle.edu.br

Supplementary Issue: Rio 2016 Olympic Games Third Anniversary Special Edition. Olympic Studies Forum, 2-3 September 2019. Federal University of Sergipe, Aracaju, Brazil.

JOURNAL OF HUMAN SPORT \& EXERCISE ISSN 1988-5202

(c) Faculty of Education. University of Alicante

doi:10.14198/jhse.2020.15.Proc1.07 


\section{INTRODUCTION}

The present research is about the validation process of the Explanatory Model of Values and Attitudes in Sport - EMVAS (Lee et al., 2008). Its goal is to explore associations among important variables of sport values (Status, Competence and Moral), motivational climate (towards the Ego and the Task) and attitudes (Pro and Antisocial), according to the EMVAS.

Human values constitute a determinant fraction in the moral development of children and young people and are still considered as a dominant influence in society. Both human values and attitudes, besides of making their own reality perception explicit, can serve either for individual and social groups' interests. In addition, it motivates to action - giving direction and intensity - and provides rules whereby the behaviour is assessed (Lee et al., 2008; Rokeach, 1981; Perron, 1987; Schwartz, 2007; Lee, Whitehead, \& Balchin, 2013, Lee, Whitehead, \& Ntoumanis, 2013). The relationship among its social groups and their own experiences favours human values maturity (Trevisol, 2009).

The practice of sports activities, formal and non-formal, for example, exerts great influence on education of young, mainly on behaviours and conducts aspects Lee, Whitehead, \& Ntoumanis, 2013, Saldanha et al., 2018). Fair Play is an example of the most known value among sports practitioners (Renson, 2009, Saldanha et al., 2018).

In order to answer the research objectives, this study shows, initially, the aspects regarding the theoretical plan relating to values (human and sporting) and, afterwards, aspects regarding empirical plan relating to this same construct. This way, it is believed to explore sufficiently the comprehension of a content present on sports practice.

Advances in concept clarification about human values were possible after the studies of Rokeach (Rokeach, 1981). The author utilized contributions from different areas (Anthropology, Philosophy, Psychology and Sociology) in order to explain this concept. The values distinction in relation to another constructs (for example, attitudes and personality) were determinants for its clarification, elaborating values system, as well as the building and the application of values measure instruments. The author postulates that a number relatively small of terminal Human Values (existence purpose) are internal points of reference which all people use for stand taken and opinion elaboration. Also, through relative position measurement of these values, it is possible to predict a wide variety of behaviours, including political affiliation and religious belief. This way, values are related with behaviour and preferences state. The value turns necessary to action, in other words, it has a normative character, which is capable to guide an action, comparisons and judgements of "I" and through other objects and specific situations. Values are abstract ideals (negative or positive) that represents beliefs of a person about conduct ideal ways. It can be said that a person has a value when it has a lasting belief, on the other hand, an attitude or action is personal and socially preferable (Rokeach, 1981, Saldanha et al., 2018, Perron, 1987). In this regard, if human values can determinate how people justify their decisions in life, consequently they will influence attitudes and behaviour in sport (Lee et al., 2008, Lee, Whitehead, \& Ntoumanis, 2013, Lee and Cockman, 2013, Portet, 2007, Lee, 2007, Malina, 2007, Saldanha et al., 2018). It is believed that the sport of social integration, in special, is an open space to build, rebuild and to mature the knowledge. Therefore, to consider it important is to bet on the future of children and young people.

From the relevance of "transmitted" values through sport and concepts that must be evaluated by the construct was possible elaborate the next questions whom guides this study: (1) Are Sport Values, 
represented by variables of 'Status', 'Competence' and 'Morals', capable to predict the 'Social-friendly Attitudes' and 'Antisocial Attitudes', according to the Explanatory Model of Values and Attitudes in Sport EMVAS?; (2) What is the existing causal relation between variables cited before with the intermediate variables of 'Task Orientation' and 'Ego Guidance'?

\section{METHODOLOGY}

The Research Ethics Committee from Federal University of Rio Grande do Sul analysed and approved the present study under the protocol number 18.193.

\section{Participants and sampling}

In the study participated 1.125 subjects $(\mathrm{nm}=687$; $\mathrm{nf}=438$ ) between the ages of 12 and 19 years old $(\bar{X}$ $=13,80 ; \mathrm{dp}=0,40$ ). These people were linked to grassroots social programs in the southern Brazil. A diversity of sports modalities were offered for them, such as tennis, soccer, volley, futsal, athletics, handball, basketball, swimming, hockey, rugby, judo, dance, jiu-jitsu, taekwondo and Muay Thai.

Most of the sample researched were male $(61,1 \%)$, aged between 12 and 15 years old $(87,2 \%)$, having been linked with projects for a year $(70,04 \%)$ and currently attending elementary school $(86,22 \%)$. Some projects, as an example, the Programa Segundo Tempo ("Second Half Program" in English) offers to the community a 12 months participation time (possible to be extended), although, there is a considerable sector of $19,1 \%$ from total sample $(n=215)$ that are linked for more than two years to their projects.

Table 1. People frequency distribution according to control variable.

\begin{tabular}{|c|c|c|c|c|c|c|c|c|c|c|c|c|c|c|}
\hline \multirow[t]{2}{*}{ Categories } & \multirow[t]{2}{*}{ Variables } & \multicolumn{2}{|c|}{ Gender } & \multicolumn{4}{|c|}{ Age-Group } & \multicolumn{3}{|c|}{$\begin{array}{l}\text { Educational } \\
\text { Level }\end{array}$} & \multicolumn{4}{|c|}{$\begin{array}{l}\text { Participation time in } \\
\text { the Project }\end{array}$} \\
\hline & & 1 & 2 & 3 & 4 & 5 & 6 & 7 & 8 & 9 & 10 & 11 & 12 & 13 \\
\hline \multirow{3}{*}{ Gender } & $M(1)$ & 687 & & & & & & & & & & & & \\
\hline & $F(2)$ & - & 438 & & & & & & & & & & & \\
\hline & 12 to 13 years old ( 3 ) & 364 & 226 & 590 & & & & & & & & & & \\
\hline \multirow{3}{*}{ Age-Group } & 14 to 15 years old (4) & 255 & 136 & - & 391 & & & & & & & & & \\
\hline & 16 to 17 years old (5) & 63 & 70 & - & - & 133 & & & & & & & & \\
\hline & 18 to 19 years old (6) & 5 & 6 & - & - & - & 11 & & & & & & & \\
\hline \multirow{4}{*}{$\begin{array}{l}\text { Educational } \\
\text { Level }\end{array}$} & Elementary School (7) & 609 & 361 & 568 & 345 & 55 & 2 & 970 & & & & & & \\
\hline & Secondary School (8) & 78 & 73 & 22 & 46 & 74 & 9 & - & 151 & & & & & \\
\hline & Graduated (9) & 0 & 4 & 0 & 0 & 4 & 0 & - & - & 4 & & & & \\
\hline & $\begin{array}{l}\text { Less than } 6 \text { months } \\
\text { (10) }\end{array}$ & 276 & 189 & 231 & 177 & 51 & 9 & 391 & 74 & 0 & 465 & & & \\
\hline \multirow{3}{*}{$\begin{array}{l}\text { Participation } \\
\text { time in the } \\
\text { Project }\end{array}$} & $\begin{array}{l}\text { From } 6 \text { months to } 1 \\
\text { year (11) }\end{array}$ & 202 & 121 & 136 & 123 & 60 & 4 & 254 & 65 & 4 & - & 323 & & \\
\hline & $\begin{array}{l}\text { From } 1 \text { year to } 2 \text { years } \\
\text { (12) }\end{array}$ & 78 & 44 & 81 & 31 & 9 & 1 & 118 & 4 & 9 & - & - & 122 & \\
\hline & More than 2 years (13) & 131 & 84 & 142 & 60 & 13 & 0 & 207 & 8 & 0 & - & - & - & 215 \\
\hline
\end{tabular}

The social projects researched had as characteristic to attend children and youngsters in social vulnerability. Therefore, the activities centres were located in places with this characteristic. In order to use sport as a means to contribute on education of these citizens, the classes were administered at least three times a week outside of school hours. It was a non-random sample, which was chose according to availability of the subjects and the social projects accessibility. 


\section{Instruments}

Questionnaire of Variable Control Identification (QVCI): (gender, age, educational level, sport type and time linked with social sportive programs).

Youth Sport Value Questionnaire 2 (YSVQ-2): The YSVQ-2 was translated, adapted and validated for Brazilian Portuguese, resulting in 27 items (Saldanha, Balbinotti, \& Balbinotti, 2015). Each item refers to a value (for example, Moral Values: Be honest, Play correctly, and others). The sample marked an increasing importance scale from one to five ( $1=$ "This idea is very little important to me"; $2=$ "This idea is not so much important to me"; 3= "More or less important - averagely important"; 4= "This idea is very important to me" and; $5=$ "This idea is very much important to me). The 27 items that composes IVJS-2 are divided in three analysis factors: "Moral Values, "Competence Values" and, "Status Values".

Questionnaire of Attitudes in Sport (QAS-16): Adapted from Questionnaire of Attitudes in Sport (QAS-23). The QAS-23 is an instrument that evaluates originally four attitudinal dimensions (Cheating, Antisportsmanship, Convention and Determination). Answers must be marked in order to know what level the person agrees (or disagrees) with attitudes declared in Inventory items. Answers to inventory will be made through a Likert type scale, ranked in five points, from (1) "disagree firmly with declaration"; to (5) "agree firmly with declaration".

Perceived Motivational Climate in Sport Questionnaire (PMCSQ-2): To assess the perception of motivational climate, will be utilized a Brazilian version of the Perceived Motivational Climate in Sport Questionnaire (PMCSQ-2) (Newton, Duda, \& Yin, 2000). PMCSQ-2 is a 33 items questionnaire answered in Likert type scale, which evaluates two dimensions (Mastery/Task and Performance/Ego) in five points: from Totally Disagree (answer 1) until Totally Agree (answer 5).

\section{Data analysis}

The results were analysed in two steps. In first step, a 'path analysis' was conducted. Initially, linear regressions using stepwise method were used to identify what variables would be significantly predictive on the Explanatory Model of Values and Attitudes in Sport; and, finally, "enterwise" method was selected to explore the contribution of the variables in explaining the phenomenon under study (values and attitudes in sport) (Abbad and Torres, 2002). On the second step of analysis the mediation of the variable Motivational Climate was tested through partial correlations. Statistical program SPSS version 20.0 was utilized using a p-value of 0,05 .

\section{RESULTS}

Explanatory Model of Values and Attitudes in Sport Test: linear regressions and 'path-analysis'.

Comprehension of the model, initially, was made by presentation of causal relations from variables analysed, illustrated according to Figures 2 and 3 and in equations from Tables 3 and 4. Concerning to dependent variable $F$ (Social-friendly Attitudes), variables A (Competence Values), B (Moral Values) and C (Status Values) have, as hypothesis, direct causal relation. Still assuming that variables $A, B$ and $C$ have indirect influence on variable $F$, that is, variables $A, B$ and $C$ have causal relation with variable $D$ (Task Orientation), and, in turn, have causal relation with variable $F$. When analysing dependent variable $F$, having as intermediate variable $E$ (Ego Guidance), the same causal relations direct and indirect presented before were perceived, however, having an indirect influence from variables $A, B$ and $C$ with variable $F$. 
Analysing the dependent variable $G$ (Antisocial Attitudes), variables A (Competence Values), B (Moral Values) and $C$ (Status Values) have, as hypothesis, a direct causal relation. Was considered, still, that variables $A, B$ and $C$ would have indirect influence with variable $G$, that is, variables $A, B$ and $C$ would have causal relation with variable $E$ (Ego Guidance), and, in turn, causal relation with variable $G$. When analysing dependent variable $G$, having as intermediate variable $D$ (Task Orientation) was identified the same causal relations direct and indirect presented before, however, having an indirect influence from variables $A, B$ and $C$ with variable $G$.

The present Model gave origin to four equations. First group of two equations refers to variable $F$ (Socialfriendly Attitudes), as dependent variable (Table 2). Second group of two equations refers to variable $G$ (Antisocial Attitudes), as dependent (Table 3). The equations presented on Tables 2 and 3 are illustrated on Figures 2 and 3.

Table 2. Two linear regression equations that had origin on Explanatory Model of Values and Attitudes in Sport, according to variable 'Prosocial Attitudes'.

\begin{tabular}{|c|c|}
\hline Dependent variable & Equation \\
\hline Prosocial Attitudes & $F=p_{1} A+p_{2} B+p_{3} C+p_{4} D+e_{1}$ \\
\hline Task Orientation & $D=p_{5} A+p_{6} B+p_{7} C+e_{2}$ \\
\hline
\end{tabular}

Table 3. Two linear regression equations that had origin on Explanatory Model of Values and Attitudes in Sport, according to variable 'Antisocial Attitudes'.

\begin{tabular}{ll}
\hline Dependent variable & Equation \\
\cline { 1 - 2 } Antisocial Attitudes & $G=p_{1} A+p_{2} B+p_{3} C+p_{4} E+e_{1}$ \\
Ego Guidance & $E=p_{5} A+p_{6} B+p_{7} C+e_{2}$ \\
\hline
\end{tabular}

Legend: $A$ = 'Competence Values'; $B$ = 'Moral Values'; C = 'Status Values'; $E$ = 'Ego Guidance'; $G$ = 'Antisocial Attitudes'.

The analyses, from 'stepwise' method, were divided in six steps. The first analysed the contribution of the variables of the values to predict 'Task Orientation' (TO). After, linear combination among the values and 'Ego Guidance' (EG) was tested. Third and fourth steps explore, both, Motivational Climate variables (TO and EG) to predict, respectively, the 'Social-friendly Attitudes' and 'Antisocial Attitudes'. Finally, fifth and sixth steps explore direct causal relations, respectively, between the values (independent variables) and 'Socialfriendly Attitudes' and between the values and 'Antisocial Attitudes'.

Table 4. Linear regressions (stepwise method): variables 'Sport Values' predicting the variable 'Task Orientation'.

\begin{tabular}{|c|c|c|c|c|c|c|c|c|}
\hline Models & $R$ & $R^{2}$ & $F$ & Sig. & Independent variable & $\beta$ & $t$ & Sig. \\
\hline & & & & & Competence Values (CV) & .384 & 10.015 & .000 \\
\hline 3 & $.438^{a}$ & .192 & 88.743 & .000 & $\begin{array}{l}\text { Moral Values (MV) } \\
\text { Status Values (SV) }\end{array}$ & $\begin{array}{l}.115 \\
-.086\end{array}$ & $\begin{array}{l}2.952 \\
-2.766\end{array}$ & $\begin{array}{l}.003 \\
.006\end{array}$ \\
\hline
\end{tabular}

aPredictors: (constant), 'Competence Values', 'Moral Values, 'Status Values'.

When analysing causal relations between the 'sport values' (CV, MV and SV) and dependent variable 'Task Orientation' (TO), is perceived, according with table above (Table 4) that were retained three models in the analysis. In significance terms, all presented a $p<0,05$. As for sign and force, variable 'SV' presented lower weight and negative sign among retained models. The combination of these retained variables in models explains $19,2 \%$ to predict Motivational Climate 'TO'. 
When changing dependent variable to 'Ego Guidance' (Table 5), results indicates that retained variables are sufficient significantly to explain EG. However, unlike previous analysis (Table 3), variable 'SV' presented a positive sign, 'CV' and 'MV' negative. This way, this linear combination origins the explanation of $9,8 \%$ of the model, predicting Motivational Climate 'EG'.

Table 5. Linear regressions (stepwise method): variables 'Sport Values' predicting the variable 'Ego Guidance'.

\begin{tabular}{|c|c|c|c|c|c|c|c|c|}
\hline Models & $R$ & $R^{2}$ & $F$ & Sig. & Independent variable & $\beta$ & $t$ & Sig. \\
\hline \multirow{3}{*}{3} & & & & & Status Values (SV) & .356 & 10.851 & .000 \\
\hline & $.313^{a}$ & .098 & 40.618 & .000 & Competence Values (CV) & -.139 & -3.421 & .001 \\
\hline & & & & & Moral Values (MV) & -.110 & -2.664 & .008 \\
\hline
\end{tabular}

aPredictors: (constant), 'Status Values', 'Competence Values', 'Moral Values'.

Causal relations between Motivational Climate (TO and EG) as predictors of 'Social-friendly Attitudes' are explored by Table 6. It is observed that only 'TO' was retained on model and significantly as predictor of 'Social-friendly Attitudes', which is explained by $23,8 \%$ of this association. When predicting 'Antisocial Attitudes' (Table 7), as much 'TO' as 'EG' were significantly predictors, presenting a sign, respectively, negative and positive. The $15,8 \%$ explains this relation.

Table 6. Linear regressions (stepwise method): Motivational Climate (EG and TO) the 'Prosocial Attitudes'.

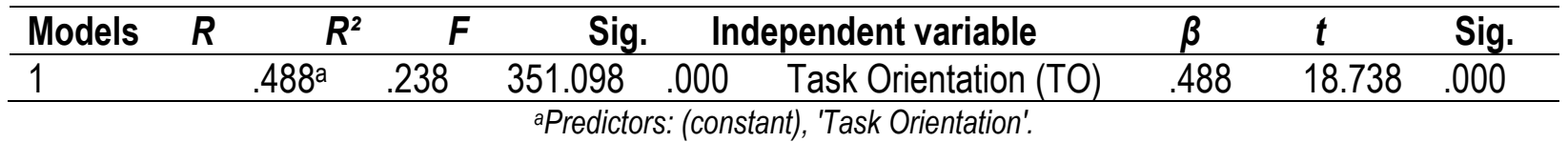

Table 7. Linear regressions (stepwise method): Motivational Climate (EG and TO) predicting the variable 'Antisocial Attitudes'.

\begin{tabular}{|c|c|c|c|c|c|c|c|c|}
\hline Models & $R$ & $R^{2}$ & $F$ & Sig. & Independent variable & $\beta$ & $t$ & Sig. \\
\hline 2 & & $.398^{a}$ & .158 & 105. & $\begin{array}{l}\text { Ego Guidance (EG) } \\
\text { Task Orientation (TO) }\end{array}$ & $\begin{array}{l}.277 \\
-.260\end{array}$ & $\begin{array}{l}10.064 \\
-9.464\end{array}$ & $\begin{array}{l}.000 \\
.000\end{array}$ \\
\hline
\end{tabular}

aPredictors: (constant), 'Ego Guidance' (EG), 'Task Orientation' (TO).

The last analysis with 'stepwise' method was between 'Values' independent variables and 'Attitudes' dependent variables. Initially, according with table below (Table 8), the model retained all independent variables (CV, MV and SV) as predictive from 'Social-friendly Attitudes'. Retention of three independent variables causes the explanation of $14,1 \%$ of model predicting 'Social-friendly Attitudes'.

Table 8. Linear regressions (stepwise method): variables 'Sport Values', predicting the variable 'Prosocial Attitudes'.

\begin{tabular}{|c|c|c|c|c|c|c|c|c|}
\hline Models & $R$ & $R^{2}$ & $F$ & Sig. & Independent variable & $\beta$ & $t$ & Sig. \\
\hline & & & & & Competence Values (CV) & .232 & 5.865 & .000 \\
\hline 3 & $.376^{a}$ & .141 & 61.446 & .000 & Moral Values (MV) & 192 & 5.197 & .000 \\
\hline & & & & & Status Values (SV)) & -.075 & -2.348 & .019 \\
\hline
\end{tabular}

aPredictors: (constant), 'Competence Values', 'Moral Values', 'Status Values.

The second analysis without intermediate variable between 'Values' and 'Attitudes' is represented on Table 9. In this analysis, the dependent variable becomes 'Antisocial Attitudes'. As in the previous model, all three 
independent variables were retained. Retention of three independent variables causes the explanation of $7,5 \%$ of model predicting 'Antisocial Attitudes'.

Table 9. Linear regressions (stepwise method): variables 'Sport Values', predicting the variable 'Antisocial Attitudes'.

\begin{tabular}{|c|c|c|c|c|c|c|c|c|}
\hline Models & $R$ & $R^{2}$ & $F$ & Sig. & Independent variable & $\beta$ & $t$ & Sig. \\
\hline & & & & & Competence Values (CV) & -.201 & -4.900 & .000 \\
\hline 3 & $.275^{\mathrm{a}}$ & .075 & 30.504 & .000 & Status Values (SV) & .212 & 6.393 & .000 \\
\hline & & & & & Moral Values (MV) & -.132 & -3.159 & .002 \\
\hline
\end{tabular}

Analysis completed by 'stepwise' method, results will be presented below from 'enterwise' method, according to variables retained on previous analysis. The diagram of Figure 1 represents causal relations through intermediate variables (TO and EG). On Figure 2, the same diagram is presented, but, the relation without intermediate variables.

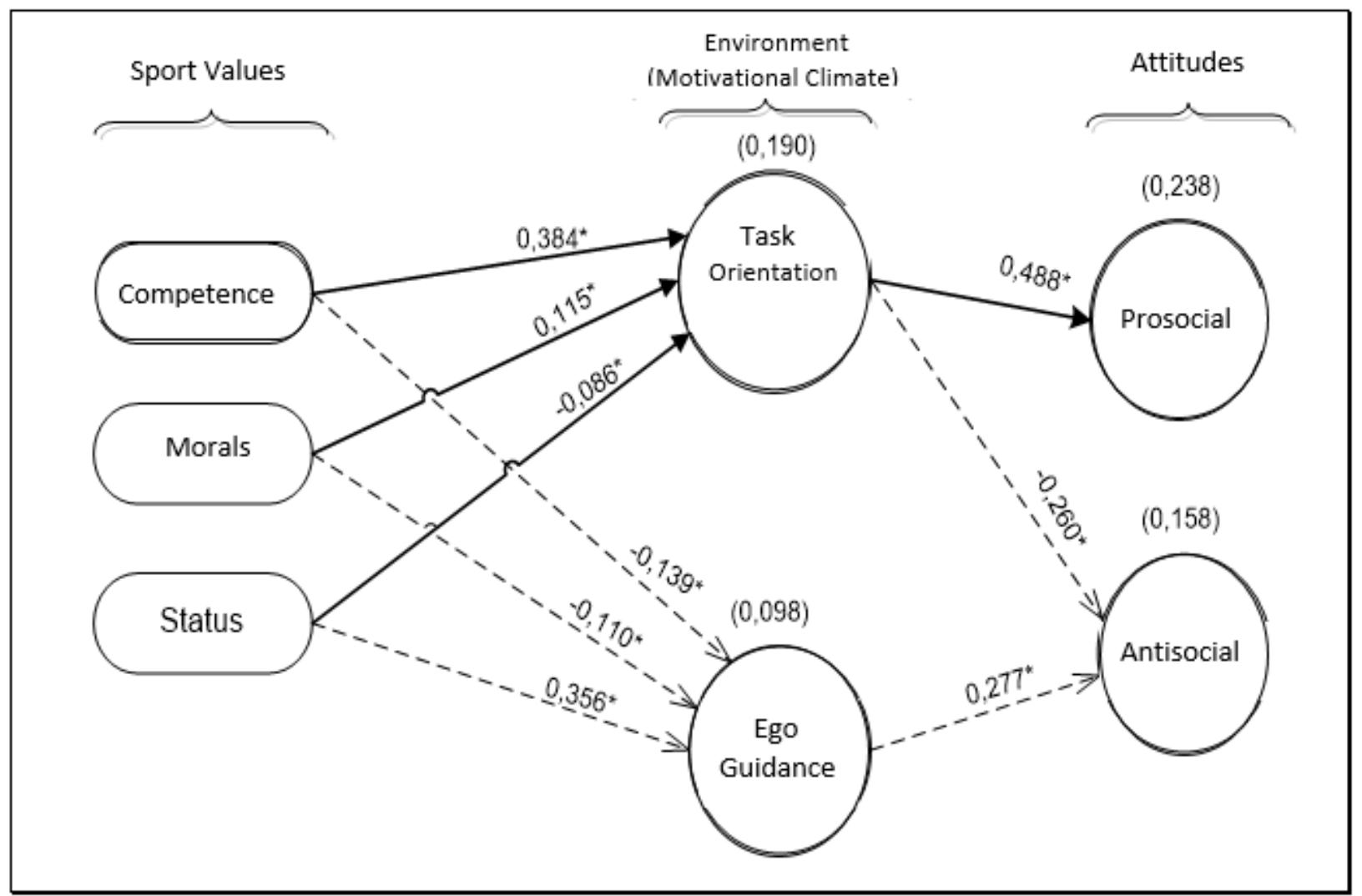

Observation: The standardized $\beta$ are above way arrows and $R^{2}$ are in parenthesis under dependent variables. ${ }^{*} p<.05$. Drawn arrows represents links to predict 'Ego Guidance' and 'Antisocial Attitudes', continuous arrows represent links to predict 'Task Orientation' and 'Prosocial Attitudes'.

Figure 1. Path Diagram of EMVAS, indicating the standardized $\beta$ and the $\mathrm{R}^{2}$, with intermediate variables link. 


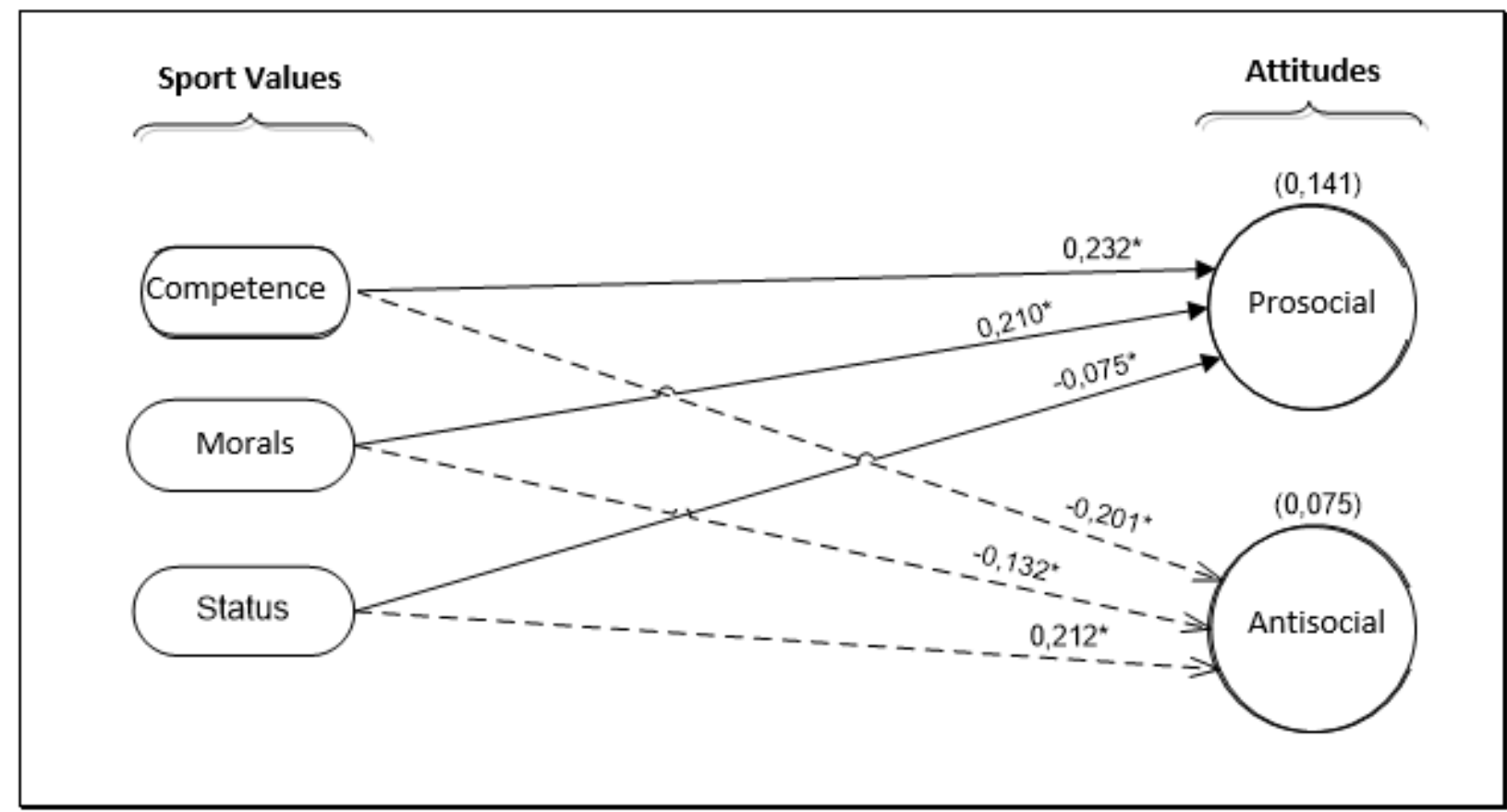

Observation: The standardized $\beta$ are under way arrows and $R^{2}$ are in parenthesis under dependent variables. ${ }^{*} p<.05$. Drawn arrows represents links to predict 'Antisocial Attitudes', continuous arrows represent links to predict 'Prosocial Attitudes'.

Figure 2. Path Diagram of EMVAS, indicating the standardized $\beta$ and the $\mathrm{R}^{2}$ without intermediated variable.

According to 'path analysis' results from Figure 1, a good data adequacy to model is observed. The relation between first step (Sport Values) and second (Motivational Climate) was in accordance with literature (Lee et al., 2008). However, is noticed that $19 \%$ of variance of variable 'Task Orientation' are explained by linear combination of variables 'CV', 'MV' and 'SV', whereas $9,8 \%$ of variance of variable 'Ego Guidance' are explained by linear combination from the same variables. When analysing relation of Motivational Climate (TO and EG) and attitudes (third step of model), 23,8\% of variance of variable 'Social-friendly Attitudes' are explained by 'TO', whereas $15,8 \%$ of variance of variable 'Antisocial Attitudes' are explained by climate 'EG' and 'TO'.

There is a good data adequacy to model when ignoring Motivational Climate variables (Figure 2). However, diagram in question (Figure 2), when compared with previous (Figure 1) presented a lower percent variance. This way, all tested links of second diagram (Figure 2) were significant ( $p<0,05$, however, is noticed that $14,1 \%$ of variance of variable 'Social-friendly Attitudes' are explained by linear combination of variables 'CV', 'MV' and 'SV', whereas 7,5\% of variance of variable 'Antisocial Attitudes' are explained by the same linear combination. Linear regressions completed using 'enterwise' method, now it is time to perform partial correlations among study variables.

\section{Mediation test among determinants from attitudes: partial correlations}

In this analysis step will be explored if motivational climate (Task Orientation and Ego Guidance) does mediation between 'Sport Values' and attitudes (Social-friendly and Antisocial).

In accordance with EMVAS, coefficients of partial correlations were calculated to test linear association of 'values' with 'attitudes', keeping constant the 'motivational climate'. Bonferroni method was used to control error type I. The analyses were tested according to models retained by 'stepwise' method (Lee et al., 2008). 
It is observed that, on first evaluation of mediation effect of 'TO' between values and 'Social-friendly Attitudes' (Table 10), as for significance, the 'status values' loses significance when 'TO' effect is controlled. In all variables (CV, MV and SV) the 'TO' does mediation to explain 'Social-friendly Attitudes'. However, 'SV' variable suffers less influence than other values when controlling 'TO' variable.

Table 10. Correlations of zero order and partials, between the 'Values' and 'Prosocial Attitudes', controlling the mediation effect of motivational climate 'Task Orientation (TO)'.

\begin{tabular}{|c|c|c|c|c|}
\hline \multicolumn{2}{|c|}{ Correlated variables } & \multicolumn{3}{|c|}{ Results } \\
\hline Predictor variable & $\begin{array}{l}\text { Foretold } \\
\text { variable }\end{array}$ & $\begin{array}{l}\text { Pearson's } r \\
\text { (zero order) }\end{array}$ & $\begin{array}{c}\text { Partial correlation } \\
\text { (mediating variables: TO) }\end{array}$ & $|\Delta r|$ \\
\hline $\begin{array}{l}\text { Competence Values (CV) } \\
\text { Moral Values (MV) } \\
\text { Status Values (SV) }\end{array}$ & $\begin{array}{l}\text { Prosocial } \\
\text { Attitudes }\end{array}$ & $\begin{array}{l}.346^{*} \\
.337^{*} \\
129^{*}\end{array}$ & $\begin{array}{l}.174^{*} \\
.206^{*} \\
.069\end{array}$ & $\begin{array}{l}.172 \\
.131 \\
.060\end{array}$ \\
\hline
\end{tabular}

Observation: * $p<0,007$ (significance index corrected by Bonferroni method to minimize error type I).

Table 11. Correlations of zero order and partials, between the 'Values' and 'Antisocial Attitudes', controlling the mediation effect of motivational climate (EG and TO).

\begin{tabular}{|c|c|c|c|c|}
\hline \multicolumn{2}{|c|}{ Correlated variables } & \multicolumn{3}{|c|}{ Results } \\
\hline Predictor variable & $\begin{array}{l}\text { Foretold } \\
\text { variable }\end{array}$ & $\begin{array}{l}\text { Pearson's } r \\
\text { (zero order) }\end{array}$ & $\begin{array}{c}\text { Partial correlation } \\
\text { (mediating variables: EG } \\
\text { and TO) }\end{array}$ & $|\Delta r|$ \\
\hline $\begin{array}{l}\text { Competence Values (CV) } \\
\text { Moral Values (MV) } \\
\text { Status Values (SV) }\end{array}$ & $\begin{array}{c}\text { Antisocial } \\
\text { Attitudes }\end{array}$ & $\begin{array}{l}-.199^{*} \\
-.172^{*} \\
.059\end{array}$ & $\begin{array}{l}-.087^{*} \\
-.084^{*} \\
-.033\end{array}$ & $\begin{array}{l}.112 \\
.088 \\
.092\end{array}$ \\
\hline
\end{tabular}

The mediation of Motivational Climate (TO and EG) to predict 'Antisocial Attitudes' is presented on Table 11. When analysing force of predictor variables (Values), the only variable which suffer mediation from Motivational Climate (TO and EG) is 'SV'. However, both in zero order and partial order correlation, the 'SV' variable remains non-significant. Nevertheless, the result points out an important indicative about mediation of Motivational Climate. It is worth reminding that association between 'SV' and 'EG' presented a positive sign, while relation of 'SV' and 'TO' was negative, and relation of 'TO' and 'EG' between 'Antisocial Attitudes' were, respectively, negative and positive. Following this logic, it can be said that 'EG' does (positive) mediation between 'SV' and 'Antisocial Attitudes'. Hereinafter, will be presented discussion of results.

\section{DISCUSSION}

The main analyses presented in this study were divided in three steps (stepwise, enterwise and partial correlations). The first is about results obtained on linear regressions by 'stepwise' and 'enterwise' (path analysis) method. These results indicate that there is causal relation among links evaluated from 'Values' (predictor variables), 'Motivational Climate' (intermediate variables) and 'Attitudes' (foretold variables). According to the studies of Lee et al, the principles of these results follows Explanatory Model of Values and Attitudes in Sport (EMVAS) (Lee et al., 2008).

As in the original study of the Lee et al. (2008) model, variance percent explained of dependent variables (Pro and Antisocial Attitudes) decreased when pathways were analysed with (Figure 1) and without mediation (Figure 2) of Motivational Climate between values and attitudes. The variance percent explained in 'Social- 
friendly Attitudes' decreased, respectively, from $23,8 \%$ (way with mediation) to $14,1 \%$ (without mediation). In the studies of Lee et al., the variance explained by the same pathway was from $17 \%$ (with mediation) and, only $0,01 \%$ without mediation. It is noticed the same percent reduction of variance in 'Antisocial Attitudes', which decreased from $19 \%$ (with mediation) to $0,03 \%$ (without mediation) in the studies of Lee et al.(2008). In the present study, as much variance percent explained without mediation (7,5\%) as in association with mediation (15,8\%), were higher than original study of Lee et al. (2008).

As mentioned earlier, values are predictors of Motivational Climate (TO and EG). This finding was also verified in study of Lee et al. (2008). The 'Status Values', contributes positively $(\beta=0,356 ; p<0,05)$ to 'EG' and negatively, and with Beta value lower, to 'TO' $(\beta=-0,086 ;<0,05)$. As much 'Competence Values' (CV) $(\beta=0,384 ; p<0,05)$ as 'Moral Values' (MV) $(\beta=0,115 ; p<0,05)$ presented positive sign as predictors of 'TO'. Predictors of 'EG' explains $9,8 \%$ of variance, whereas predictors of 'TO', $19,2 \%$.

The reference of ' $\mathrm{CV}$ ' is in self-direction, self-monitoring of its learning, motivational climate characteristic for mastery (TO) (Caetano and Januário, 2009). 'Moral Values' refers to an obligation feeling (La Taille, 2006a), like obedience, justice, pleasure, support, etc. (Lee et al., 2008), and tends to be more evident in learning environments focused on task (TO), generating more social-friendly attitudes. In contrast, the 'SV' are related with appreciation of a public image, of a winner (Lee et al., 2008), similar characteristic of a motivational climate of 'EG'. This climate, in addition to encourage this appreciation, tends to generate 'Antisocial Attitudes' among students (Lee et al., 2008, Caetano and Januário, 2009, Camargo, Hirota, \& Verardi, 2008, Hirota et al., 2011).

Lee et al. (2008) pointed out in his study that expectancy of variable 'MV' is not predictor of social attitudes. The authors, even not accepting other studies cited in its article, believed that 'MV' does not have any achievement element and, consequently the mediations (Motivational Climate) were not had effect to predict social attitudes. Its conclusions about this fact, were opposite of its expectations (Lee et al., 2008).

In accordance with Rokeach Theory, values are behaviours mode or preference state, in other words, are psychological instances that leads to attitudes (Rokeach, 1981). This way, cognitive processes are fundamental to a person decides what to do (Perron, 1987).

In moral problems field, the cognitive development is necessary condition of moral sense, but not sufficient condition to moral action, because the question remains of the motivation (La Taille, 2006a). These processes are fundamentally associated with life experience of each person and serves to evaluate situations that can occur in life and sport.

In addition to motivational aspect, affectivity also should be considered in this process. The affectivity determines desirability in each person, in other words, a value under the form of desire or obligation, whereby ambient exerts significant influence while determines standards and behaviours. However, the interest in adopting some behaviour type (individualistic or collectivist) depends of process relations and moral conscious from person (Perron, 1987, La Taille, 2006a, Vecchione et al., 2016).

The moral conscious, from the intellectual point of view, arises by the age of 4-5 years old. This conscious is the capacity to make difference among the things "that are done" and those that "must be made". Such a heteronomous phase of person, according with Piaget, family is the main values depositary. Obeying to moral rules, for example, is to respect what represents to itself the rules source (Piaget, 1994). According with La 
Taille, the kid respects because its parents or responsible for upbringing inspires fear and love (simultaneously) (La Taille, 2006b).

Piaget understood the mix of fear and love as unilateral respect. This way, kid have fear to be penalized, censured and mainly, lose love of parents (Piaget, 1994). In contrast, La Taille believes that love and fear are not sufficient to explain the complexity of moral sense maturity only with authority relation. There are other feelings hitched with two mentioned, for example: reliability, kindness, indignation, guilt and shyness (La Taille, 2006b).

For a certain time (classic philosophy), the moral was understandable as duties collection to be followed. Still having those premises, what will determine a conduct like good or bad will be reason ("how should I act?"). This reason is translated in feelings, like happiness, angry and sadness, in addition to feelings, which integrates personality of a person, which can propel itself to a moral action.

Moral action is linked with moral reasoning and process of decision taking (Wiese-Bjornstal, Lavoi, \& Omli, 2009). Adopting a climate for mastery (Task Orientation) in class can favour development of morals in youngsters sport practitioners. Because provides reflection to students about effect of its actions according with all group and colleagues, applying decision taking democratically (collectively), making them more autonomous.

As mentioned earlier, young people researched in this study have age from 12 years. However, many projects, including the researched, allows attending kids from seven years old. This way, cognitive process understanding until phase that these youngsters comes for Physical Education teacher it is of fundamental importance.

Piaget holds the logic that heteronomy passage to autonomy occurs with 12 years old (Piaget, 1994). The heteronomous moral, previous described, can be exemplified as an action which kid or young performs by justifying it under the authority of the adult, resulting on not admit or recognize consequence of the acts; whereas in autonomous moral, the person governs itself. This way, to "achieve" this autonomy, feelings previously mentioned should passed by an intellectual maturity, in which the teacher must be attentive in these details.

Third analysis step is about partial correlations. This analysis aimed to identify the existence of an intermediate variable (mediating). When confirming the existence, and if bivariate correlation between two variables not equal to zero, indicates that variables $A$ and $B$ (for example) are associated, because the first explains the second by consequence of influence of a mediating variable (Field, 2015; Pestana and Gageiro, 2014). Results indicated that 'TO' is a mediating variable from 'Social-friendly Attitudes'. When variable 'TO' is controlled, partial correlation results suffered considerable decrease in variables 'CV' and 'MV' when predicting 'Social-friendly Attitudes'.

In addition of being a mediator which facilitates 'Social-friendly Attitudes' (Lee et al., 2008, Camargo, Hirota, \& Verardi, 2008, Hirota et al., 2011, Marante and Ferraz, 2006, Santos, 2007). The 'TO' is essential for the development of youngsters learning in sport. In accordance with literature aforementioned, this climate favours a higher engagement of student on tasks proposed by teacher, generating a higher and intrinsic motivation (Ryan and Deci, 2007; Vierling, Standage, \& Treasure, 2007) consequently a higher engagement with activity. This engagement occurs, because students oriented to task tends to be worry with task domain, 
aims learning, are self-reference to competence perception, tends to persist more in activities and handle better with failure situations (Santos, 2007; Caetano and Januário, 2009).

The results of 'TO' effect (negatively) and 'EG' (positively) as predictor of 'Antisocial Attitudes' indicated that variable 'SV' is the only which suffers influence from mediating variable in question. Literature points out that an 'EG' climate have strong influence on generating antisocial attitudes (Lee et al., 2008; Camargo, Hirota, \& Verardi, 2008; Hirota et al., 2011; Marante and Ferraz, 2006, Santos, 2007; Smoll, Smith, \&Cumming, 2007). Students with this guidance have Social-friendly attitudes only with successful activities (Caetano and Januário, 2009). In addition, students who have profile of demonstrate that its capacity is higher than its colleague prefers success without effort; have difficulties on handling with failure; searches positive judgments and avoid negative; tends not to value effort; makes whichever is needed to win; and, tends to be motivated by external elements, in other words, reasons related with social status. This way, teacher experience or person responsible by class is decisive for the adoption of an ego-guidance or task-orientation climate (Gonçalves et al., 2010).

\section{CONCLUSIONS}

From the present study was possible to test the Explanatory Model of Values and Attitudes in Sport - EMVAS from Lee et al. (2008) and, from its results, is possible to conclude that EMVAS is valid to explain relation among values, motivational climate and attitudes of young people who practices sport in social projects in southern Brazil, aged between 12 and 19 years old. The data presented has a relevant contribution for studies in the area in question.

It is important to alert that the quality of social relations performs a fundamental role in this process, because when teacher points out, for example, mutual respect value and cooperation feeling, it can contribute in a decisive way to moral development of the youngsters.

Finally, some limitations and suggestions for new studies will be presented. The limitation that is more stood out is related with the methodology cut of the present study (transverse). It is suggested that new studies are made from a longitudinal cut, aiming to observe from a longer perspective the relation process among study variables. It is also suggested that new variables are added in EMVAS, as coping, competence perception and motivation (Self-Determination Theory). The first relates with cognitive and behaviours efforts of person aiming to deal with situations demanded to itself. The second would have the objective to exhibit values relation, mediated by a motivational climate (EG or TO). The third, in accordance with some studies, presents a relation of values in affectivity aspect (Perron, 1987; Schwartz, 2007; Vecchione et al., 2016; Torres, Schwartz, \& Nascimento, 2016, Gouveia, 2003). It is also relevant to point out that, for studies in different regions of Brazil, would be interesting to change values scale, adding negative points aiming to identify, from measurable values, which one would be opposite of what young people most valorise.

\section{REFERENCES}

Abbad, G., \& Torres, C.V. (2002). Regressão múltipla stepwise e hierárquica em Psicologia Organizacional: aplicações, problemas e soluções. Estudos de Psicologia (Natal), 7(spe), 19-29. https://dx.doi.org/10.1590/S1413-294X2002000300004

Caetano, A., \& Januário, C. (2009). Motivação, teoria das metas discentes e competência percebida. Pensar a Prática, 12(2), 1-12. https://doi.org/10.5216/rpp.v12i2.5891 
Camargo, F.P., Hirota, V.B., \& Verardi, C.E.L. (2008). Orientação motivacional na aprendizagem esportiva na escola. Revista Mackenzie de Educação Física e Esporte,7(3), 53-62.

Field, A. (2015). Descobrindo a estatística usando o SPSS. Artmed.

Gonçalves, Carlos Eduardo, Silva, Manuel João Coelho e, Cruz, Jaume, \& Figueiredo, Antonio. (2010). Efeito da experiência do treinador sobre 0 ambiente motivacional e pedagógico no treino de jovens. Revista Brasileira de Educação Física e Esporte, 24(1), 15-26. https://dx.doi.org/10.1590/S180755092010000100002

Gouveia, Valdiney V.. (2003). A Natureza Motivacional Dos Valores Humanos: Evidências acerca de uma nova tipologia. Estudos de Psicologia (Natal), 8(3), 431-443. https://dx.doi.org/10.1590/s1413$294 \times 2003000300010$

Hirota, V.B., Hayashi, D.H., Marco, A., \& Verardi, C.E.L. (2011). A influência da orientação motivacional durante 0 treinamento de atletas iniciantes no tênis de campo. Revista Mackenzie de Educação Física e Esporte 10(2), 11-20.

La Taille, Y. (2006a). Saber fazer moral: a dimensão intelectual. In: La Taille, Y. (Ed), Moral e Ética: dimensões intelectuais e afetivas (pp. 71-105). Artmed. https://doi.org/10.24220/23180870v24n1a4232

La Taille, Y. (2006b). O querer fazer moral: a dimensão afetiva. In: La Taille, Y. (Ed), Moral e Ética: dimensões intelectuais e afetivas (pp. 107-150). Artmed. https://doi.org/10.24220/23180870v24n1a4232

Lee, M.J, Whitehead, J., \& Balchin, N. (2013). The measurement of values in youth sport: Development of the Youth Sport Values Questionnaire. In: Whitehead, J.; Telfer, H.; Lambert, J. (Eds). Values in youth sport and physical education (pp. 49-65). Routledge/Taylor \& Francis Group. https://doi.org/10.1037/t25951-000

Lee, M.J. (2007). Sport, education and society: the challenge. In: Cumming, S.P., Silva, M.J.C., Malina, R.M., Gonçalves, C.E. (Eds), Sport and Education: Tribute to Martin Lee (pp. 197-207). Imprensa da Universidade de Coimbra. http://dx.doi.org/10.14195/978-989-26-0474-9_17

Lee, M.J., \& Cockman, M. (2013). Values in children's sport: Spontaneously expressed values among young athletes. Whitehead, J.; Telfer, H.; Lambert, J. (Eds), Values in youth sport and physical education (pp. 37-48). Routledge/Taylor \& Francis Group. https://doi.org/10.1177/101269029503000307

Lee, M.J., Whitehead, J., \& Ntoumanis, N. (2013). Development of the Attitudes to Moral Decisions in Youth Sport Questionnaire. IN: Whitehead, J., Telfer, H., \& Lambert, J. (Eds). Values in youth sport and physical education (pp. 66-84). Routledge/Taylor \& Francis Group. https://doi.org/10.1037/t20390-000

Lee, M.J., Whitehead, J., Ntoumanis, N., \& Hatzigeorgiadis, A. (2008). Relationships Among Values, Achievement Orientations, and Attitudes in Youth Sport. Journal of Sport and Exercise Psychology, 30(5), 588-610. https://doi.org/10.1123/jsep.30.5.588

Malina, R.M. (2007). Benefits and risks of participation in organized youth sports. In: Cumming, S.P., Silva, M.J.C., Malina, R.M., Gonçalves, C.E. (Eds), Sport and Education: Tribute to Martin Lee (pp. 57-71). Imprensa da Universidade de Coimbra. http://dx.doi.org/10.14195/978-989-26-0474-9_17

Marante, W.O.; \& Ferraz, O.L.(2006). Clima motivacional e educação física escolar: relações e implicações pedagógicas. Motriz (Rio Claro) 12(3), 201-216.

Newton, M., Duda, J.L., \& Yin, Z. (2000). Examination of the psychometric properties of the perceived motivacional climate in sport questionnaire-2 in a sample of female athletes. Journal of Sport Sciences 18(4), 275-290. https://doi.org/10.1080/026404100365018

Perron, J. (1987). Bases e Aplicações dos Valores em Psicologia e Educação. Sagra. 
Pestana, M.H., \& Gageiro, J.G. Análise de dados para ciências sociais: a complementaridade do SPSS (6th ed.). Edições Silabo. https://doi.org/10.13140/2.1.2491.7284

Piaget, J. (1994). O juízo moral na criança. Translation Elzon Lenardon. Summus.

Portet, X.G. (2007). Los valores em el deporte: una experiencia educativa a través del Barça-Madrid. Revista Científica de Comunicación y Educación, 28, 148-156. https://doi.org/10.3916/c28-2007-14

Renson, R. (2009). Fair play: its origins and meanings in sport and society. Kinesiology, 41(1), 5-18.

Rokeach, M. (1981). Crenças, atitudes e valores. Ed. Interciência.

Ryan, R.M., \& Deci, E.L. (2007). Active Human Nature: Self-Determination theory and the promotion and maintenance of sport, exercise, and health. In: Hagger, M.S., \& Chatzisarantis, N.L.D. (Eds.), Intrinsic motivation and self-determination in exercise and sport (pp.1-19). Human Kinetics. https://doi.org/10.1016/i.psychsport.2007.06.003

Saldanha, R.P., Balbinotti, M.A.A., \& Balbinotti, C.A.A. (2015). Tradução e validade de conteúdo do Youth Sport Value Questionnaire 2. Revista Brasileira de Ciências do Esporte, 37(4), 383-388. https://dx.doi.org/10.1016/..rbce.2015.08.010

Saldanha, R.P., Evangelista, P.H.M., Florentino, J.A.A., Balbinotti, M.A.A., \& Balbinotti, C.A.A. (2018). Atitudes morais de atletas juvenis no esporte de competição: um estudo com praticantes do futebol de campo. Revista Brasileira de Futsal e Futebol, 10(9), 428:438. https://doi.org/10.31501/rbpe.v8i1.9322

Santos, C.M.G. (2007). Motivação e esporte: uma intervenção das metas de realização em jovens atletas. Tese de Doutorado Universidade de Brasília, Brasília, Brasil.

Schwartz, S.H. (2007). Universalism values and the inclusiviness of our moral universe. Journal of crosscultural psychology, 38(6), 711-728. https://doi.org/10.1177/0022022107308992

Smoll, F.L., Smith, R.E., \& Cumming, S.P. (2007). Coaching behaviors, motivational climate, and Young athletes's Sport experiences. In: Cumming, S.P., Silva, M.J.C., Malina, R.M., Gonçalves, C.E. (Eds), Sport and Education: Tribute to Martin Lee (pp. 165-175). Imprensa da Universidade de Coimbra. http://dx.doi.org/10.14195/978-989-26-0474-9_17

Torres, Cláudio V., Schwartz, Shalom H., \& Nascimento, Thiago G.. (2016). The Refined Theory of Values: associations with behavior and evidences of discriminative and predictive validity. Psicologia USP, 27(2), 341-356. https://dx.doi.org/10.1590/0103-656420150045

Trevisol, M.T.C. (2009). Tecendo os sentidos atribuídos por professores do ensino fundamental ao médio profissionalizante sobre a construção de valores na escola. In: La Taille, Y., Menin, M.S.S. (Eds). Crise de valores ou valores em crise? (pp.152-184). Artmed. https://doi.org/10.1590/s010373312003000100002

Vecchione M., Schwartz, S., Alessandri, G., Döring, A.K., Castellani, V., \& Caprara, M.G. (2016). Stability and change of basic personal values in early adulthood: An 8-year longitudinal study. Journal of Research in Personality 63, 111-122. https://doi.org/10.1016/j.jrp.2016.06.002

Vierling, K.K., Standage, M., \& Treasure, D.C. (2007). Predicting attitudes and physical activity in "atrisk" minority youth sample: a test of self-determination theory. Psychology of Sport and Exercise, 8(5), 795-817. https://doi.org/10.1016/..psychsport.2006.12.006

Wiese-Bjornstal, D.., LaVoi, N. M., \& Omli, J. (2009). Child and adolescent development and sport participation. In Brewer, B.W. (Ed.), Handbook of sports medicine and science. Sport psychology (p. 97-112). Wiley-Blackwell. https://doi.org/10.1002/9781444303650.ch10

\section{(9) $\odot \Theta \Theta$}

This work is licensed under a Attribution-NonCommercial-NoDerivatives 4.0 International (CC BY-NC-ND 4.0). 